\title{
The effect of beauty vocational training institutions on the satisfaction of trainees
}

\author{
*Bo-kyeung Kim, Ph.D.student, Dept. Of Smart Convergence Consulting, Hansung University, 02876, \\ Seoul,Korea,Kbk7655@naver.com \\ Yen-yoo You, Professor, Dept. Of Smart Convergence Consulting, Hansung University, 02876, Seoul, Korea, \\ threey0818@hansung.ac.kr
}

*Corresponding Author

\begin{abstract}
Background/Objectives: This study was intended to examine the impact of the educational environment on satisfaction among trainees of beauty vocational training institutions. The educational performance of beauty vocational training institutions was set to the satisfaction level of students and the influence of factors such as educational environment, teaching method, and instructor capacity was to be verified.

Methods/Statistical analysis: In order to establish theoretical concepts through the study of literature on prior research and to identify the variables in the educational environment and verify their impact on satisfaction, a research model and research theory will be established and an empirical analysis will be conducted through the questionnaire. We would like to analyze the relationship between independent variables such as educational environment and dependent variables such as teaching method and instructor competency's influence on trainee satisfaction. The survey was conducted on 180 beauty trainees in Seoul and Gyeonggi-do, and the collected data was analyzed using AMOS 22.0

Findings: The results of this study are as follows. The educational environment has been shown to have a significant effect on teaching methods and teaching competencies. The teaching method has been shown to have a significant definition effect on trainee satisfaction. In the competency section of the instructor, it was shown to have a significant negative effect on trainee satisfaction.

Improvements/Applications: This study confirmed that the educational environment factors and teaching skills are variables that affect the satisfaction of trainees. Therefore, in order to improve the satisfaction level of trainees at beauty training institutions, the quality of education should be improved first by improving the quality of education environment and developing various teaching methods.
\end{abstract}

Keywords: vocational training, educational environment, teaching methods, instructor competency, satisfaction

Received: 09.12.2020 Accepted: 17.01.2021 $\quad$ Published: 04.02.2021

\section{INTRODUCTION}

With the recent spread of the K-Beauty industry around the world and growing interest in beauty education in Korea, the importance of fostering human resources in beauty vocational training institutions has emerged, and the approach to seeing and learning systematic and scientific professional skills has become important, not just supplier-oriented, but consumer-oriented education. This study aims to present the direction of vocational training education through fostering vocational training institutions and developing vocational skills through empirical verification of the changing environment of beauty vocational training institutions and the causal relationship between variables of vocational training institutions' educational environment, teaching methods, and instructor competency on trainees' satisfaction.

Vocational training is a training system in which the government entrusts the training of the unemployed to a training institution for the improvement of the employment or basic job competency of the unemployed or provides the expenses to the unemployed in the event of self-training, and is divided into support of the training institution and personal support of the trainees according to the method of subsidizing the training expenses [1]

Beauty education institutions need policies to improve the satisfaction of trainees by systemizing education support systems, such as information and support related to education and training, and providing field-oriented education contents and physical environment such as various curricula, educational facilities, and equipment. [2].

As a result of studying the effects of vocational training courses and student satisfaction, 
recommendation intentions and characteristics, and the impact of student satisfaction and recommendation on vocational training courses and student satisfaction on recommendation intentions, the higher the satisfaction level of vocational training courses, the higher the recommendation intention and student satisfaction level [3].

When the educational environment forms a relationship that actively supports the learning atmosphere of educational institutions, learners feel happier and participate more actively in educational activities [4].

The results showed that the level of knowledge of teachers and instructors, the content of lectures, the preparation of classes, the ties with trainees, the professionalism of teachers and instructors, and the observance of class hours have an excellent effect on satisfaction [5].

The benefits and satisfaction level of cooking education programs were measured for students who completed cooking education courses at vocational schools, and the structural equation model was examined to determine whether teachers' skills and satisfaction with education and education facilities acted as parameters between cooking education programs and educational environment, and performance satisfaction and achievement. As a result, higher benefits and parameters such as benefits, educational environment, teacher skills, and educational facilities for educational programs, the higher the achievement, or satisfaction, of trainees. [6]

Trainees who are receiving education at vocational education and training institutions were studied to understand the impact of satisfaction with educational services and educational environment provided by vocational education institutions on their recommendation intentions. As a result, the quality of educational services such as instructor level, educational curriculum, and educational contents should be improved, and the quality of teaching atmosphere and facility environment should be high. It also said that in order to increase the recommendation intention, the quality of the teaching atmosphere, which is an educational service, an educational curriculum, and an educational environment, should have a positive effect on the recommendation intention [7].

Higher benefits and parameters, such as effectiveness of the training process, educational environment, competence of instructor competency, and training facilities, have shown higher achievement or satisfaction of the trainees, and the overall content of vocational school education has a positive impact on the satisfaction of the trainees [3]

As a result of analyzing the causal relationship between the components that affect education services and customer satisfaction and repurchase, educational facilities, instructors, and operating services have a significant impact on customer satisfaction, and as a result, customer satisfaction affects repurchase [8].

Student satisfaction was defined as subjective experience during college life and recognition of the value of educational experience [9].

\section{Materials and Methods}

\subsection{Collecting data}

This paper was surveyed through e-mail questionnaire to study structural factors affecting trainee satisfaction in beauty industry. 180 valid samples were used in the study, except for 7 unfaithful respondent questionnaires. The scale of the survey was a five-point recurved scale, and the empirical analysis of the collected data was done using the AMOS 22.0 statistical tool.2.2.

\subsection{Research model}

Based on the existing theoretical basis and prior study, this study established a research model to analyze the motivational factors of the educational environment affecting trainee satisfaction.

Through previous prior studies, we wanted to understand the impact relationship between independent variables such as educational environment and dependent variables such as teaching methods, instructor competency, and satisfaction.

The research model of this study is shown in Figure 1.

Figure 1. Research model 


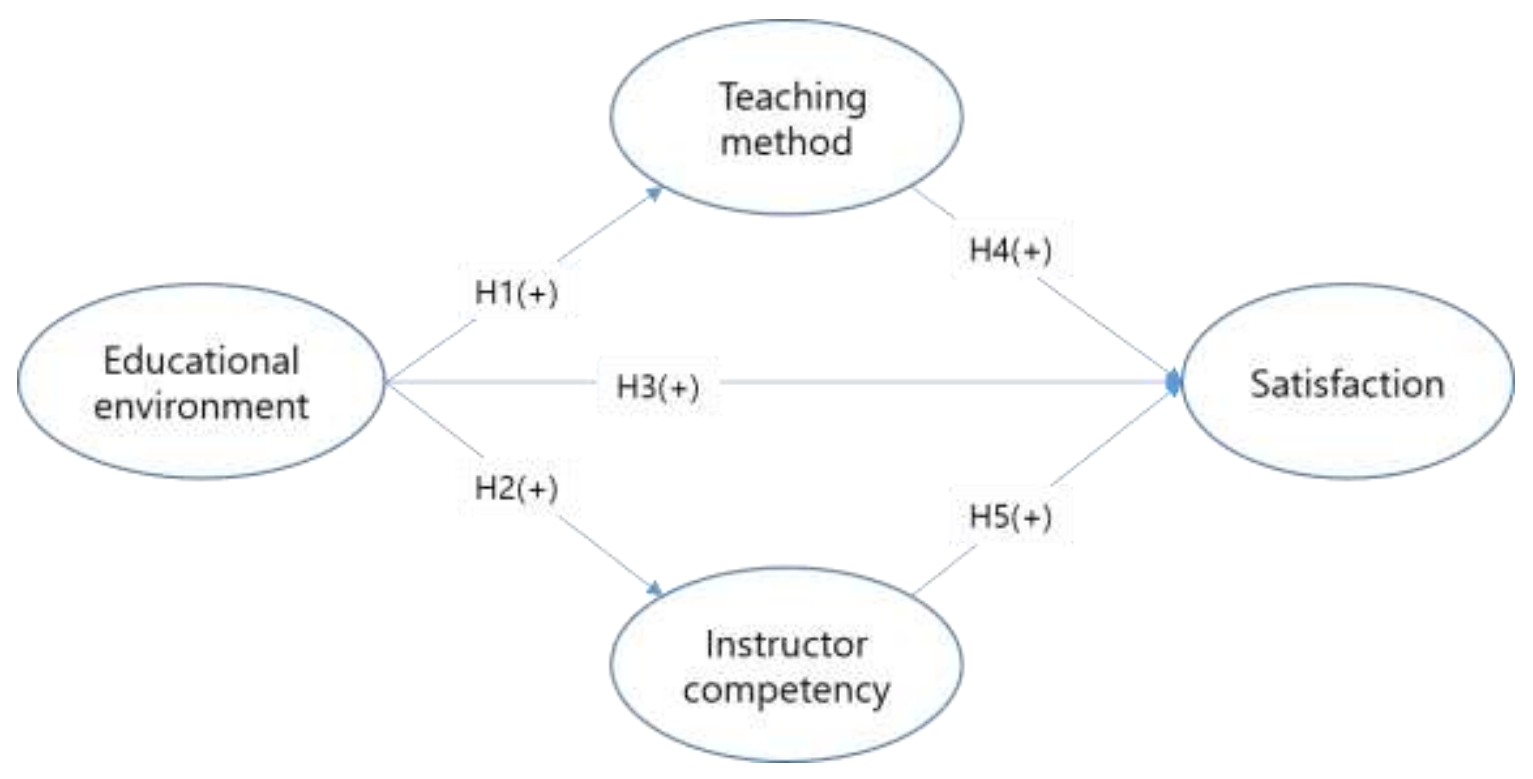

\subsection{Research Hypothesis}

This study established a study theory to determine the causal relationship between embedded variables based on prior research. The research theories are described in detail as follows.

H1. The educational environment will have a positive influence on teaching methods

H2. The educational environment will have a positive impact on instructor competency.

H3. The educational environment will have a positive influence on the satisfaction of trainees.

$\mathrm{H} 4$. The teaching method will have a positive effect on the satisfaction of trainees.

H 5. Instructor competency will have positive influence on satisfaction.

\subsection{Operational Definition of Variables}

In this study, all measurement questions adopted to ensure their relevance were used in the existing literature and selected from measured items that have been empirically validated and manipulated as Tab le 1 to meet the purpose of this study

Table 1: Questionnaire

\begin{tabular}{|c|c|c|c|c|}
\hline Research & Operative definition & Measured item & Associated research & \\
\hline $\begin{array}{l}\text { Educational } \\
\text { environment }\end{array}$ & $\begin{array}{l}\text { The degree of facility } \\
\text { equipment, } \\
\text { employment } \\
\text { support, } \\
\text { administrative } \\
\text { services, etc., which } \\
\text { are physical factors of } \\
\text { vocational training }\end{array}$ & $\begin{array}{l}\text { - Suitability of the educational } \\
\text { environment } \\
\text { - Sufficiency of training } \\
\text { equipment } \\
\text { - Comfortability of practical } \\
\text { facilities } \\
\text { - Rapidness of administrative } \\
\text { services } \\
\text { - Diversity of providing job } \\
\text { start-up information } \\
\text { - Job placement status }\end{array}$ & $\begin{array}{l}\text { Park Won suk } \\
(2017)[10] \\
\text { Yang Tae sig } \\
(2004)[5]\end{array}$ & 7 \\
\hline $\begin{array}{l}\text { Teaching } \\
\text { method }\end{array}$ & $\begin{array}{l}\quad \text { Degree of } \\
\text { application of teaching } \\
\text { methods }\end{array}$ & $\begin{array}{l}\text { - Adequacy of Theory and } \\
\text { Practice Lecture } \\
\text { - Whether to conduct } \\
\text { individual guidance } \\
\text { - Whether a practical } \\
\text { demonstration }\end{array}$ & Kim Mi & 4 \\
\hline
\end{tabular}




\begin{tabular}{|c|c|c|c|c|c|}
\hline & & $\begin{array}{l}\text { - Whether feedback after } \\
\text { presenting the correct } \\
\text { problem }\end{array}$ & & & \\
\hline $\begin{array}{l}\text { Instructor } \\
\text { competency }\end{array}$ & $\begin{array}{l}\text { degree of instructor } \\
\text { competence }\end{array}$ & $\begin{array}{l}\text { - Teaching expertise } \\
\text { - Sincerity of training } \\
\text { preparation } \\
\text { - Systematic training content } \\
\text { - The understanding of } \\
\text { trainees } \\
\text { - Provide employment sense }\end{array}$ & $\begin{array}{l}\text { Enos(2001)[12] } \\
\text { Yang Tae } \\
(2004)[5]\end{array}$ & Sik & 7 \\
\hline satisfaction & $\begin{array}{l}\text { The degree of trainees' } \\
\text { satisfaction with } \\
\text { beauty education }\end{array}$ & $\begin{array}{l}\text { - The kindness } \\
\text { administrative staff } \\
\text { - Conformity of education } \\
\text { contents } \\
\text { - Condition of training } \\
\text { facilities and equipment } \\
\text { - System of training } \\
\text { institutions } \\
\text { - System of employment } \\
\text { support }\end{array}$ & $\begin{array}{l}\text { Anderson\&Sullivan } \\
(1993)[9] \\
\text { Park Jung } \\
(2014)[3]\end{array}$ & Ran & 6 \\
\hline \multicolumn{2}{|c|}{ Demographics } & \multicolumn{3}{|c|}{ Sex, Age, Education, Occupation, etc } & 4 \\
\hline
\end{tabular}

\section{Results and Discussion}

\subsection{Statistical analysis results}

\subsubsection{Measurement model analysis}

For the data collected for this study, AMOS 22.0 was used to test the measurement model and to analyze the structural equation model.

In order to secure the centralized validity among the variables suggested in the research model and to perform path analysis, confirmatory factor analysis was performed between the measured variables

As shown in Table 2, when the standardized loading values are all 0.5 or more, and the average variance extraction value is 0.5 or more, convergence validity is secured at the current level. In addition, it can be said that the convergence validity or internal consistency is high because the composite reliability of each component concept is higher than 0.7 RMSEA

In the structural equation model, the fit of each model was judged based on TLI, GFI, CFI, and

As a result of evaluating the fit of the model, the chi-square is $286.375(\mathrm{df}=164), \mathrm{CMIN} / \mathrm{df}=1.746$, which is smaller than the standard value of 3.0, GFI is .857, slightly lower than the standard value of 0.90 , TLI is .945, CFI is .952 Good fit, RMSEA $=.067$, which is higher than the standard value of 0.90 , is less than or equal to 0.1 , so it can be said that the fit of the model is good compared to the main indicators used as general evaluation criteria

The results of the evaluation of the measurement model are as Table 2

Table 2 : Evaluation of the measurement model

\begin{tabular}{|c|c|c|c|c|c|c|c|c|}
\hline $\begin{array}{l}\text { Latent } \\
\text { variable }\end{array}$ & $\begin{array}{l}\text { Measured } \\
\text { variable }\end{array}$ & Coefficient & $\begin{array}{l}\text { Standardiza } \\
\text { tion } \\
\text { coefficient }\end{array}$ & S.E. & C.R. & SMC & AVE & CR \\
\hline \multirow{5}{*}{$\begin{array}{l}\text { Educational } \\
\text { environment }\end{array}$} & EE2 & 1 & 0.767 & & & 0.588 & \multirow{5}{*}{0.706} & \multirow{5}{*}{0.923} \\
\hline & EE3 & 1.121 & 0.823 & 0.098 & 11.428 & 0.677 & & \\
\hline & EE4 & 1.065 & 0.831 & 0.092 & 11.572 & 0.691 & & \\
\hline & EE5 & 1.085 & 0.815 & 0.096 & 11.293 & 0.664 & & \\
\hline & EE6 & 1.147 & 0.825 & 0.1 & 11.474 & 0.681 & & \\
\hline
\end{tabular}




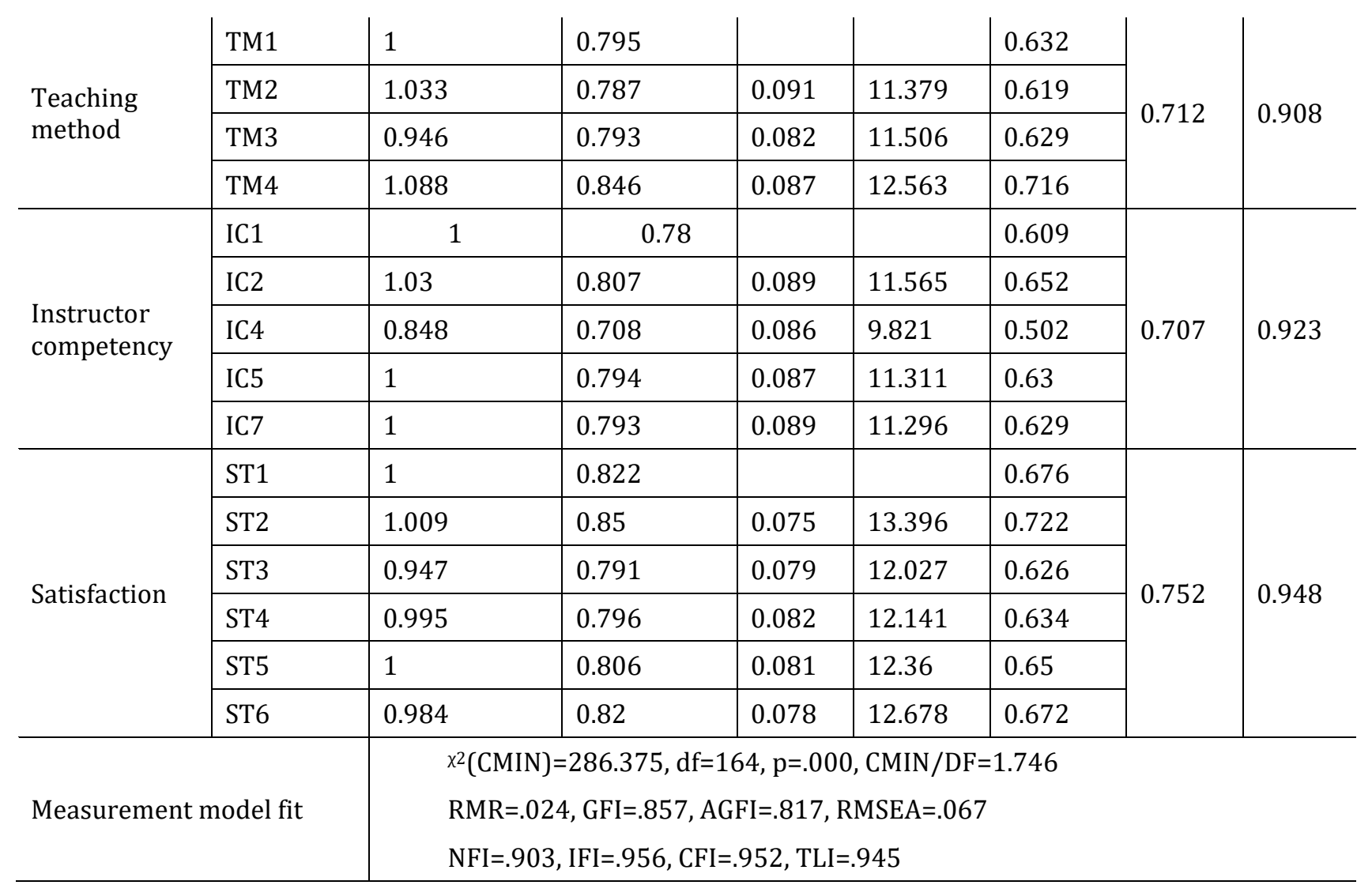

\subsubsection{Discriminant validity analysis}

To evaluate discriminant validity, the correlation coefficient between concepts and the square root value of AVE were compared.

As a result of the verification of the validity of the difference, the value of the coefficient of difference between the teaching method and the concept of the composition of the instructor's competence is. It was a high correlation of 97.

The results of the discriminant validity analysis are shown in Table3

Table3. Results of Discriminant Feasibility Analysis

\begin{tabular}{|c|c|c|c|c|}
\hline variable name & $\begin{array}{l}\text { Educational } \\
\text { environment }\end{array}$ & Teaching method & $\begin{array}{l}\text { Instructor } \\
\text { competency }\end{array}$ & Satisfaction \\
\hline $\begin{array}{l}\text { Educational } \\
\text { environment }\end{array}$ & 0.840 & & & \\
\hline Teaching method & $\begin{array}{ll}0.946 & * * * \\
(.062) & \end{array}$ & 0.844 & & \\
\hline $\begin{array}{l}\text { Instructor } \\
\text { competency }\end{array}$ & $\begin{array}{l}0.936 \quad * * * \\
(.057)\end{array}$ & $\begin{array}{l}0.97 \quad * * * \\
(.060)\end{array}$ & 0.841 & \\
\hline Satisfaction & $\begin{array}{l}0.909 \quad * * * \\
(.057)\end{array}$ & $\begin{array}{l}0.93 \quad * * * \\
(.060)\end{array}$ & $\begin{array}{ll}0.739 & * * * \\
(.057) & \end{array}$ & 0.867 \\
\hline
\end{tabular}

${ }^{*} \mathrm{p}<.05,{ }^{* *} \mathrm{p}<.01,{ }^{* * *} \mathrm{p}<.001$. The figure in ( ) is the standard error value of covariance.

\subsubsection{Hypothesis test result}

The results of the main hypothesis test through path significance analysis of the study model are as 
follows.

Table 4. Summary of Multi- regression Analysis Results

\begin{tabular}{l|l|l|l|l|l|l|l}
\hline Hypothesis & Path & coefficient & $\begin{array}{l}\text { Standardization } \\
\text { coefficient }\end{array}$ & S.E. & C.R. & P & Result \\
\hline H1 & $\begin{array}{l}\text { Teaching } \\
\text { method<-- } \\
\text { Educational } \\
\text { environment }\end{array}$ & 1.001 & 0.973 & 0 & 10.536 & $* * *$ & Accept \\
\hline $\mathrm{H} 2$ & $\begin{array}{l}\text { Instructor } \\
\text { competency<-- } \\
\text { Educational } \\
\text { environment }\end{array}$ & 0.919 & 0.965 & 0.09 & 10.264 & $* * *$ & Accept \\
\hline $\mathrm{H} 3$ & $\begin{array}{l}\text { satisfaction<-- } \\
\text { Educational } \\
\text { environment }\end{array}$ & -0.335 & -0.338 & 0.572 & -0.586 & 0.558 & rejection \\
\hline $\mathrm{H} 4$ & $\begin{array}{l}\text { satisfaction<-- } \\
\text { Teaching method }\end{array}$ & 0.302 & 0.313 & 0.357 & 0.846 & 0.398 & rejection \\
\hline $\mathrm{H} 5$ & $\begin{array}{l}\text { satisfaction<-- } \\
\text { Instructor } \\
\text { competency }\end{array}$ & 1.037 & 0.996 & 0.392 & 2.645 & $* * *$ & Accept \\
\hline
\end{tabular}

As a result of hypothesis test, the $\mathrm{P}$ value of $\mathrm{H} 1, \mathrm{H} 2, \mathrm{H} 5$ was adopted because it was $* * *$, and $\mathrm{P}$ value of $\mathrm{H} 3$ and $\mathrm{H} 4$ was rejected, representing 558, 398.

\subsubsection{Structural Model Analysis}

The result of the structural model analysis of the research model is as follows

Figure $2 . \quad$ Confirmatory factor

analysis

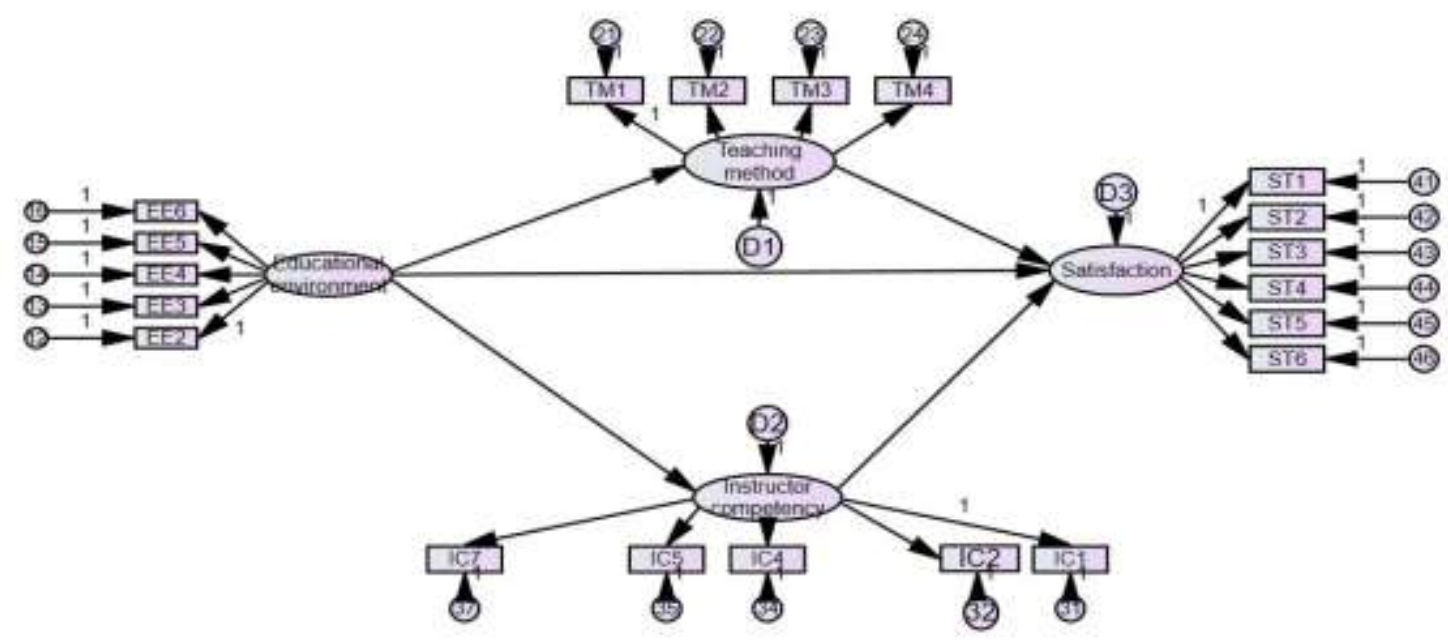

\section{Conclusion}

In this study, the structural factors affecting the training satisfaction of vocational training in beauty training institutions were investigated.

The purpose of this paper is to identify the requirements of trainees using beauty vocational training institutions and to provide information that can make the operation of training institutions more systematic and systematized.

For this purpose, a research model was designed and verified through empirical analysis to identify the impact of the educational environment of vocational training institutions on trainees' satisfaction by 
using teaching methods, instructor competency, and trainee satisfaction as subordinate variables.

The theoretical implications of this study are that the educational environment needs to be improved as the educational environment is the main variable in teaching methods and instructor competency of beauty education institutions.

Second, it is deemed necessary for instructors to develop specialized competencies in order to enhance the satisfaction level of trainees.

The practical implications are first to improve the educational environment with facilities and equipment suitable for education and training, and to prepare an environment to support the capacity development of instructors.

Second, the recruitment of new students by training institutions has a great impact on the competitiveness of educational institutions, so various teaching methods and pools of excellent instructors are needed to enhance the satisfaction of trainees.

Despite the above meaning, there is a limit to this study.

First, the educational environment, an independent variable, should be further subdivided.

Second, this study focused on beauty-related vocational training institutions, but it is necessary to expand and study leading factors as it seems that there is a slight lack of research on prior factors considering the expertise of beauty vocational training institutions.

\section{Acknowledgment}

This research was financially supported by Hansung University.

\section{References}

[1] Jeong, S. J.(2014) The Relationship among TVET Service Quality,Training Satisfaction and Employability of Unemployed Vocational Trainees. Asia-pacific Journal of Multimedia Services Convergent with Art, Humanities, and Sociology, Vol.7 No.12 pp1-283(1)

[2] Kim, Y(2017). A Study on the Effect of Educational Environment Factors affecting Self-Efficacy and Educational Performance in the Beauty Vocational Training Institute. Asia-pacific Journal of Multimedia Services Convergent with Art, Vol.7, No.12,pp. 217-225. http://dx.doi.org/10.14257/ajmahs.2017.12.28

[3] Park, J. R(2014). The effect recommended on Satisfaction of a vocation training educational program relation for the cosmetic. Masters dissertation, Nambu University, Gwangju.

[4] Berger,P,andNevhausJ(1977). To Empower People - The Role of Mediating Structures in Public Policy. American Enterprise Institution for Public Policy Research Washington, D.C, p77 125

[5] Yang, T. S.(2005). (A) study on educational service quality to affect student satisfaction and recommendation purpose in Korean universities. Masters dissertation, Kyunggi University, Seoul.

[6] Ahn, E. J. (2010). A Study on the Influence of Satisfaction and Achievement which comes from the Educational Programs of Cooking by the Vocational Training Institute. Masters dissertation, Kyunggi University, Seoul.

[7] Lee, J. W. (2013). Effects of education service and educational environment of culinary vocational training institutes on satisfaction and recommendation intention of trainees : focusing on Busan and Gyeongnam area. Masters dissertation, Dongui University, Busan.

[8] Kim, J. H. (2011). (An) empirical study on the effect of education service quality on customer satisfaction and re-purchase : focusing on life-long education center. Doctoral dissertation, Seokyeong University, Seoul.

[9] Anderson \& Sullivan. (1993). The Antecedents and Consequences of Customer Satisfaction for Firms. Marketing Science, 12(2), PP125 43, https://doi.org/10.1287/mksc.12.2.125.

[10] Park.W.S. (2018). Effect of training environment in the private cooking vocational training institution on the satisfaction level of the trainees : focusing on NCS training institutions. Masters dissertation, Uiduk University, North Gyeongsang Province.

[11] Kim, M J. (2007). The Effects of Teaching-Learning Methods on the Academic Attitude and Achievement toward Mathematics Learning with Underachievers. Masters dissertation, Daegu University, Daegu

[12] Enos, M. D . (2001). Informal learning and the transfer of learning : How manages develop proficiency. Doctoral dissertation, University Of Connecticut, Connecticut. 254 285. 